\title{
THE PRODUCTION CAPACITY OF LEACHATE COLECTED FROM PIATRA NEAMT LANDFILL
}

\author{
MIHAI-COSMIN BELCIU ${ }^{1}$, ALEXANDRA-DANA CHIȚIMUS ${ }^{*}{ }^{1}$, VALENTIN \\ NEDEFF $^{1}$, NARCIS BÂRSAN ${ }^{1}$, RUSU DRAGOȘ ${ }^{1}$ \\ 1 "Vasile Alecsandri” University of Bacau, Calea Marasesti 157, Bacau, 600115, Romania
}

\begin{abstract}
Lately it was seen an growth and range broadening of activities in all sectors of economy and society and therefore, the management of waste is a problem facing the entire planet. This paper purpose an analysis of a Romanian Landfill, concerning leachate production. Mathematical models applied on landfill products create an environmental background in which concerns waste management in Romania.
\end{abstract}

Keywords: landfill, leachate, model, moisture content

\section{INTRODUCTION}

Bacterial decomposition of organic matter and organic contaminants extract ions using solvent effect of water from waste, leads to the formation of leachate. In this process, the leachate gets a light gray liquid form, pungent, characterizing the anaerobic decomposition produced inside the warehouse $[1,2]$.

It is important to know that a correct characterization of a landfill implies a number of parameters that are necessary to be involved in mathematical calculation. In which concern Romanian landfills, it is known that the concept of ecological landfill started after 2000, when some administrators create different structures in which they started to put different types of waste [1].

This paper purpose a characterization of landfill production capacity of a Romanian landfill. The location of Piatra Neamt landfill (Figure 1) is in mentioned city, General N. Dascalescu street. This city is located in the major meadow area of the Bistrița river [1-7].

The landfill is developed in cells, horizontally formed on a daily basis. The compaction degree for the layers of waste is $0.8 \mathrm{t} / \mathrm{m}^{3}$. This landfill accept industrial waste only mixed with municipal solid waste. They use soil and gravel (as solid waste), constructions and demolitions waste to cover the deposited and compacted waste, daily. Maximum thickness provided by these processes is $10 \mathrm{~cm} \mathrm{[1,3-7].}$

The landfill is distributed on two cells [1, 3-7]:

- A 2 ha cell (number 1) with a volume of $125.000 \mathrm{~m}^{3}$, closed in 2010;

- A 2.8 ha cell (number 2) with a storage capacity of $300.000 \mathrm{~m}^{3}$. Cell number 2 is on the western side of the Cell number 1 .

This landfill process the collected waste as follows [1, 3-7]:

- In a sorting station is processed some waste as glasses, plastic, beverages of aluminium, cardboard and paper. This waste is considered recyclable;

\footnotetext{
${ }^{*}$ Corresponding author, email: dana.chitimus@ub.ro

(C) 2016 Alma Mater Publishing House
} 
- Composting/crushing stations transform in aprons some waste like construction or demolition pieces;

- Grand household waste is collected in different categories;

- Non-hazardous municipal solid waste is collected from the waste generators, transported and delivered for final storage to the landfill.

- The waste generators take, transport and get the solid municipal waste to the final depot of landfill.

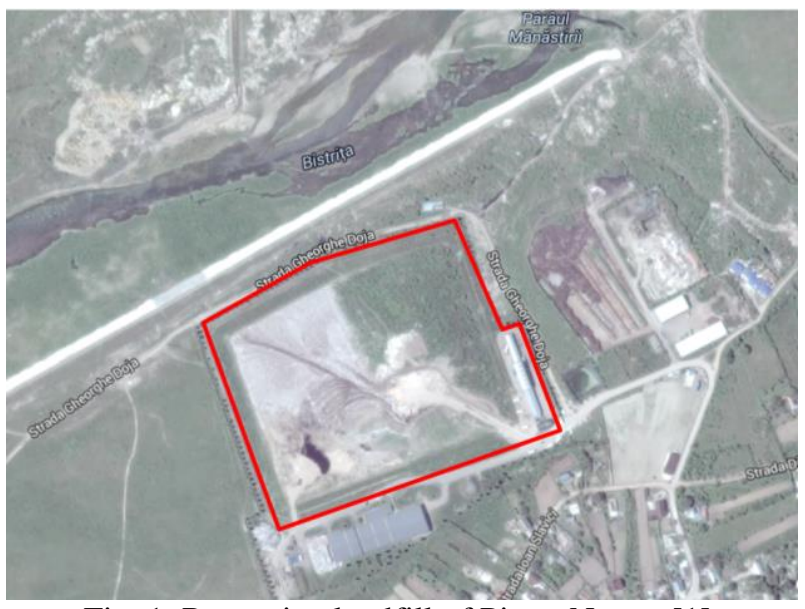

Fig. 1. Romanian landfill of Piatra Neamt [1]

An advantage of this area where the landfill is located, is the existence of a network that connects sewage treatment plant to it. Thus, the leachate can be pre-treated at the scene to fit the norms stipulated by local law. With four points collects leachate storage cells, then pumped using electric pumps in a tank [1, 3-7].

A reverse osmosis plant, located in three containers carried leachate treatment. The maximum flow rate of wastewater supported by this station is of $40 \mathrm{~m}^{3} /$ day [1, 3-7].

\section{EXPERIMENTAL SETUP}

The total waste quantity stored in Piatra Neamt landfill, during its active phase can be observed in Figure 2 [1].

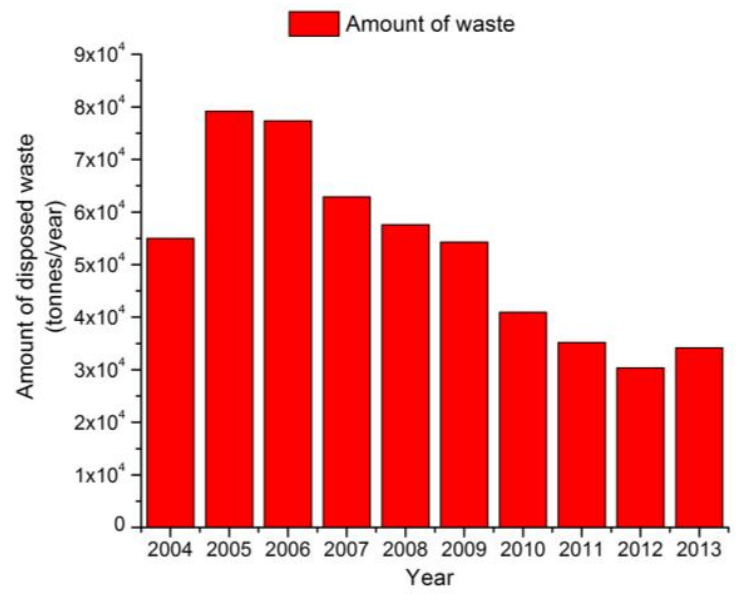

Fig. 2. The total waste quantity deposited in Piatra Neamt landfill, Romania [1, 3-7].

Piatra Neamt landfill deposit different types of waste, different as the structure of municipal solid or analogue waste. They were not used in the calculation process. Figure 3 show the average values for the fractions of municipal solid waste, kept in this landfill [1]. 


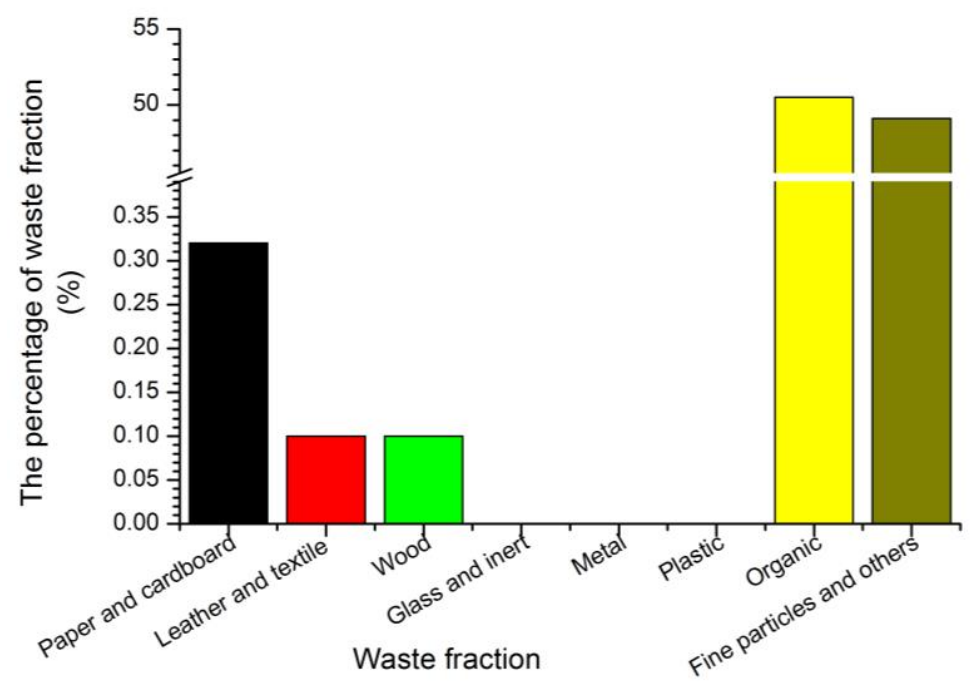

Fig. 3. The average percentage for municipal solid waste composition, kept in Piatra Neamt landfill [1, 3-7].

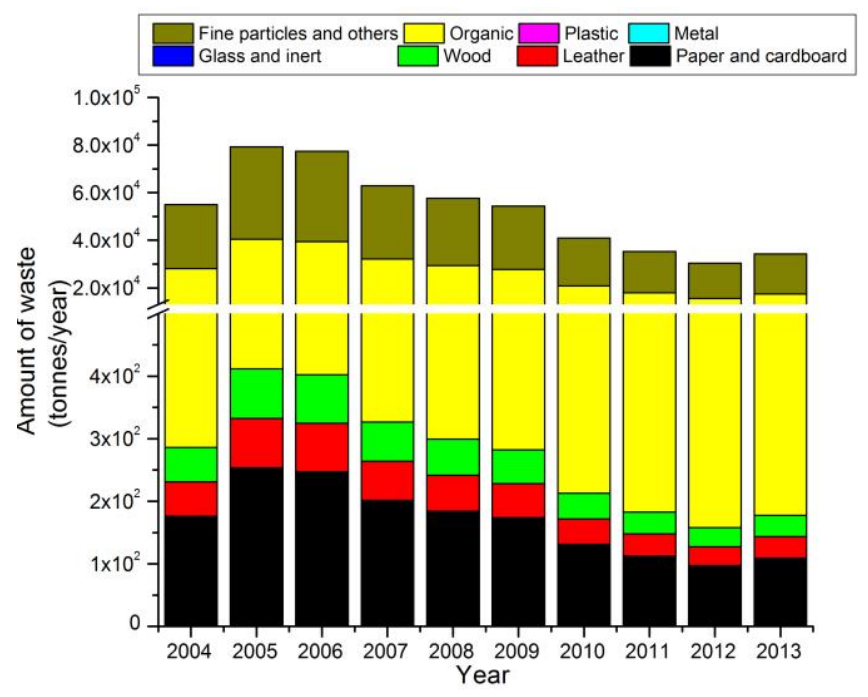

Fig. 4. The quantitative representation for municipal solid waste composition, kept in Piatra Neamt landfill [1].

The conclusion is that the fraction percentage of glass, metal and plastic are not shown. The existence of presorting section before final storage is the cause of this thing. Figure 4 represents the fraction structure for the waste amount kept in Piatra Neamt landfill, as an overview of the municipal solid waste composition [1].

Some data collected by Romanian Institute of Meteorology and Hydrology have been used (climatological and meteorogical parameters) and there have been calculated the following parameters [1]:

- the monthly average variation of precipitations for Piatra Neamt landfill, Romania for a period between 2004 and 2013 (Figure 5);

- the monthly average variation of temperature for Piatra Neamt landfill, Romania for a period between 2004 and 2013 (Figure 6).

For Piatra Neamt landfill, Romania, it was calculated the monthly average variation of runoff using equation (1), which is represented in Figure $7[1,9]$.

$$
R=c \cdot P
$$

where $R$ and $P$ represents the runoff and the precipitations expressed in the same unit measure $(\mathrm{mm} /$ day; $\mathrm{mm} /$ month), c - empirical coefficient which is evaluated at the maximum flow rate during important precipitations in short periods of time. 


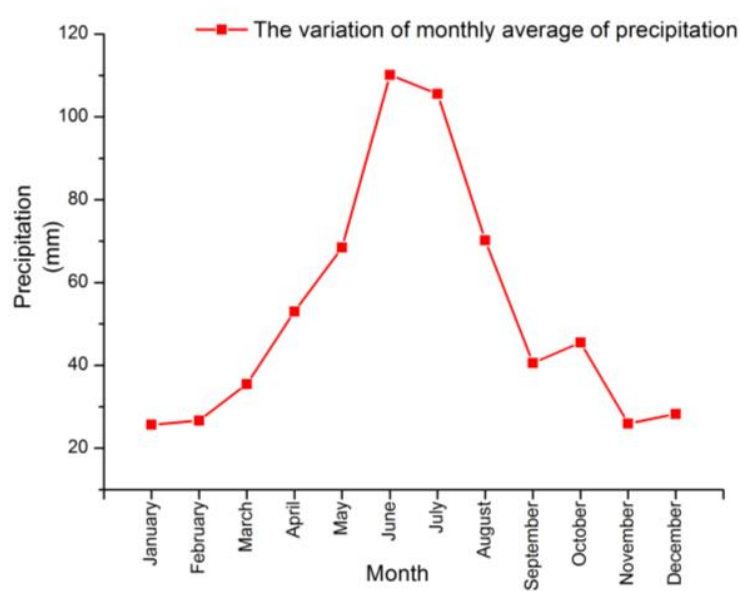

Fig. 5. The monthly average of precipitations fluctuationfor Piatra Neamt landfill, Romania $[1,8]$.

The monthly variation for evapotranspiration was calculated for Piatra Neamt landfill, Romania using equation (2) (Figure 8) [1].

$$
P E_{i}=16 \cdot\left(\frac{10 \cdot T_{i}}{I_{t}}\right)^{\alpha} \cdot C_{i}[\mathrm{~mm} / \mathrm{month}]
$$

where $P E_{i}$ represents the potential evapotranpiration considered in $i$ mounth $(\mathrm{mm} / \mathrm{month}), T_{i}-$ average temperature considered in i month $\left({ }^{0} \mathrm{C}\right), \alpha$ - dimensioned coefficient which depends by the value of $\mathrm{I}_{\mathrm{t}}, I_{t}-$ european thermal index, anually calculated, expressed using equation (3), $C_{i}$ - correction factor for every month considered.

$$
I_{t}=\sum_{i=1}^{12}\left(\frac{T_{i}}{5}\right)^{1.514}
$$

In order to estimate the liquid amount that can be produced in the landfill, the meteorological/climatological parameters were used, due to their monthly average variations [1].

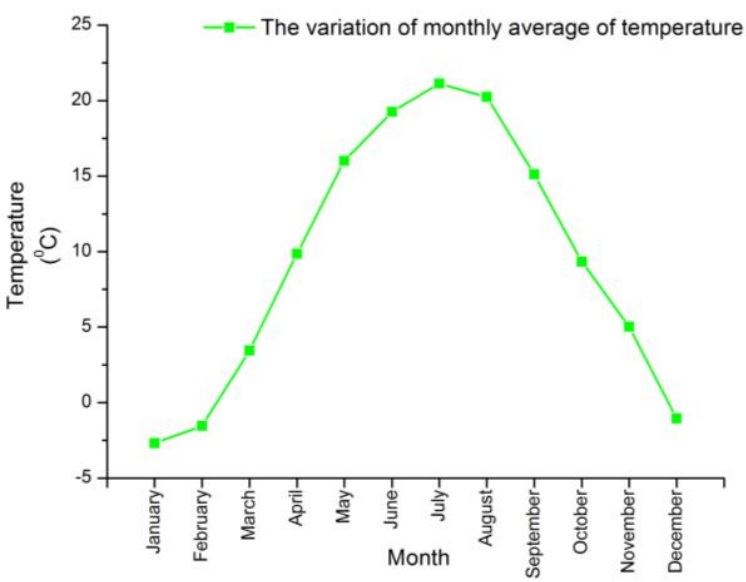

Fig. 6. The variation of monthly average of temperature for Piatra Neamt landfill, Romania [1, 8]. 


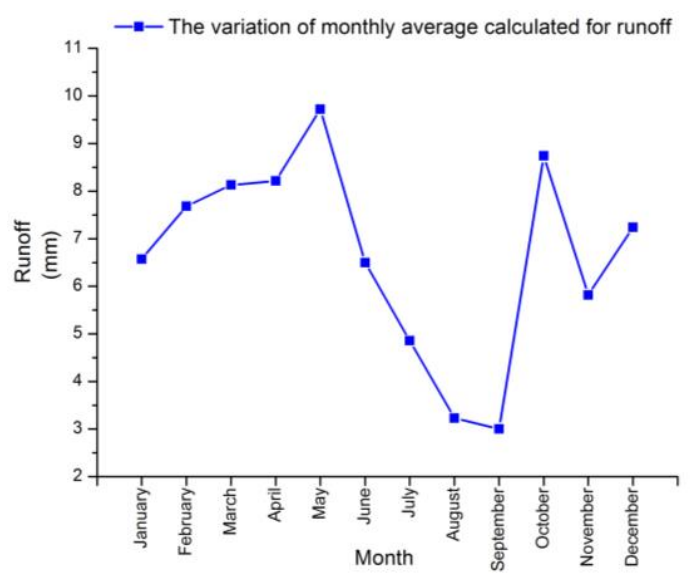

Fig. 7. The variation of monthly average of runoff calculated for Piatra Neamt landfill, Romania [1].

Given that in some months, the monthly average temperatures are negative, the evapotranspiration values of those months were not considered [1].

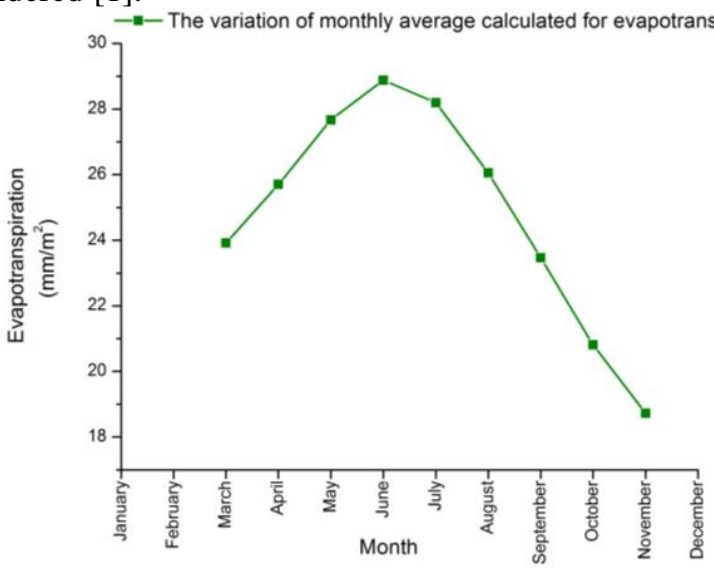

Fig. 8. The variation of monthly average of evapotranspiration calculated for Piatra Neamt landfill, Romania [1].

Taking into consideration Figures 3 and 4, which presents the deposited waste structure, it can be estimated the moisture content of each fraction of waste deposited in the mentioned landfill, and by adding liquid fractions together, the total liquid quantity generated in the landfill can be evaluated [1]. Some estimations were made for the moisture content of the waste fractions of paper and cardboard, leather and textile, wood, organic waste and fine particles of waste (Figures $9 \div 13$ ) [1]. In Piatra Neamt landfill, there were stored several types of waste, but in calculations there were taken into account only the municipal waste quantities. Industrial and construction wastes were neglected, being considered substitutes of the soil used to periodically cover the landfill layers [1].

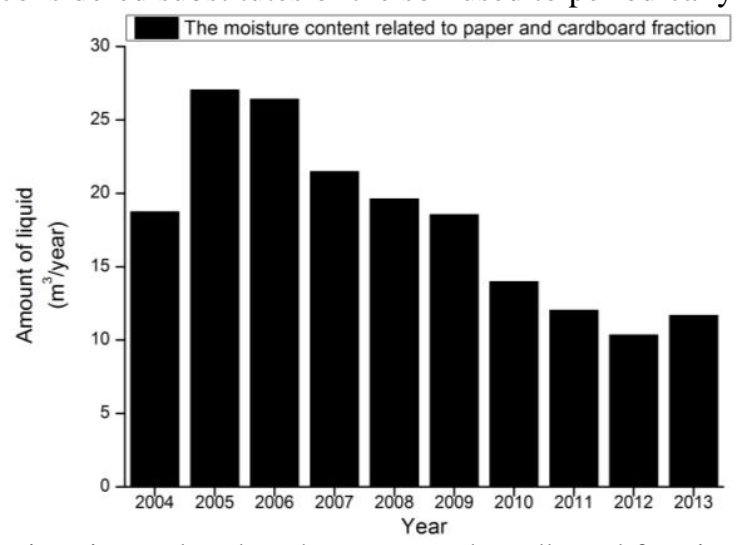

Fig. 9. The moisture content estimation, related to the paper and cardboard fraction of municipal solid waste kept in Piatra Neamt landfill [1]. 


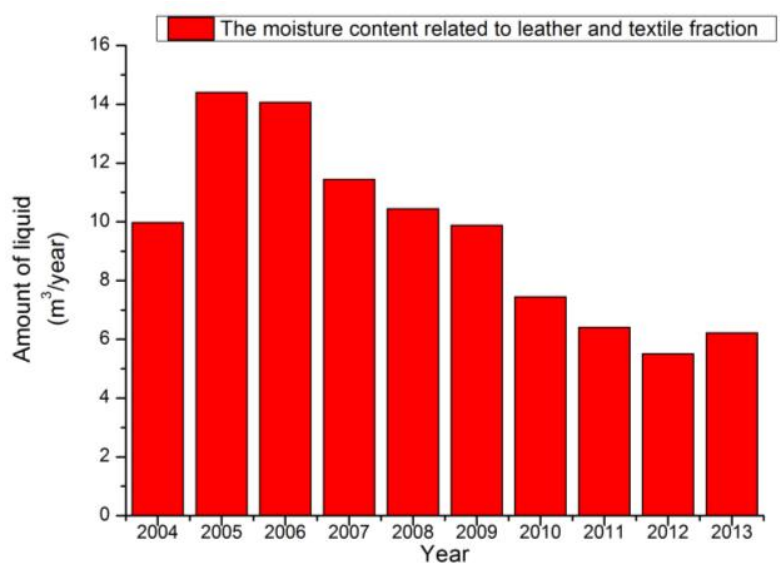

Fig. 10. The moisture content evaluation, related to the leather fraction of municipal solid waste kept in Piatra Neamt landfill [1].

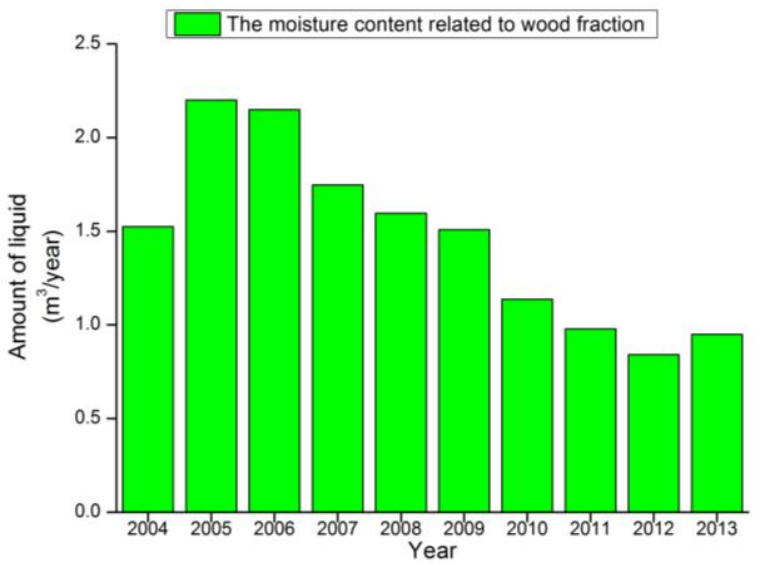

Fig. 11. The moisture content evaluation, related to the wood fraction of municipal solid waste kept in Piatra Neamt landfill [1].

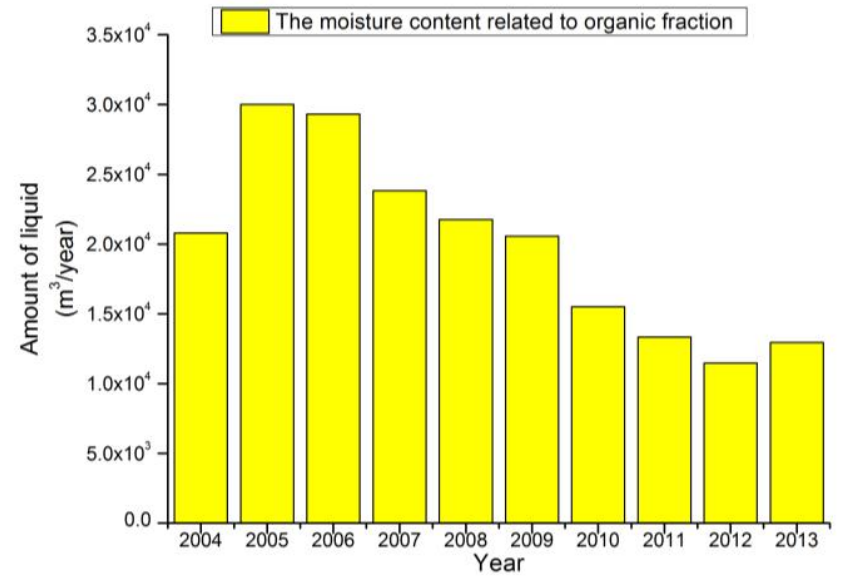

Fig. 12. The moisture content evaluation, related to the organic fraction of municipal solid waste kept in Piatra Neamt landfill [1]. 


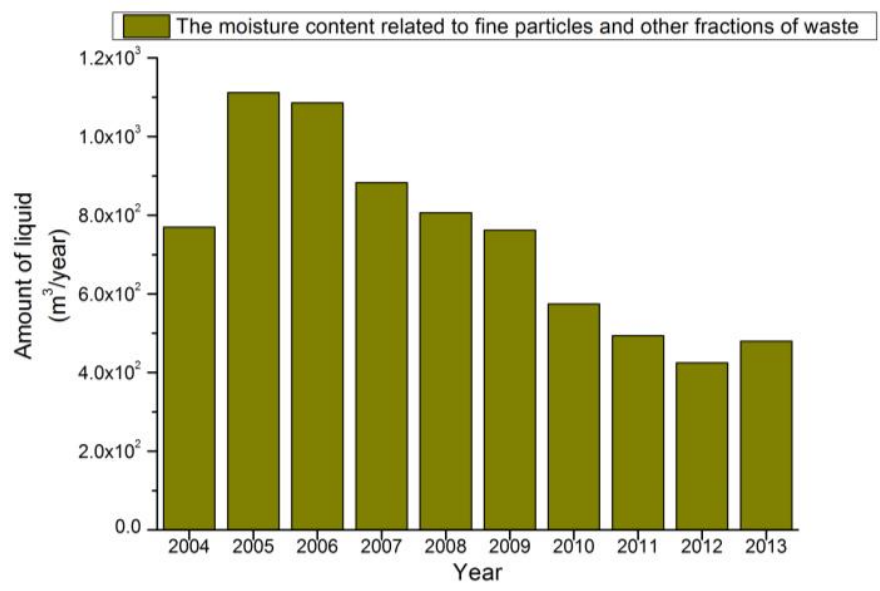

Fig. 13. The moisture content evaluation, related to the fine particles fraction of municipal solid waste kept in Piatra Neamt landfill [1].

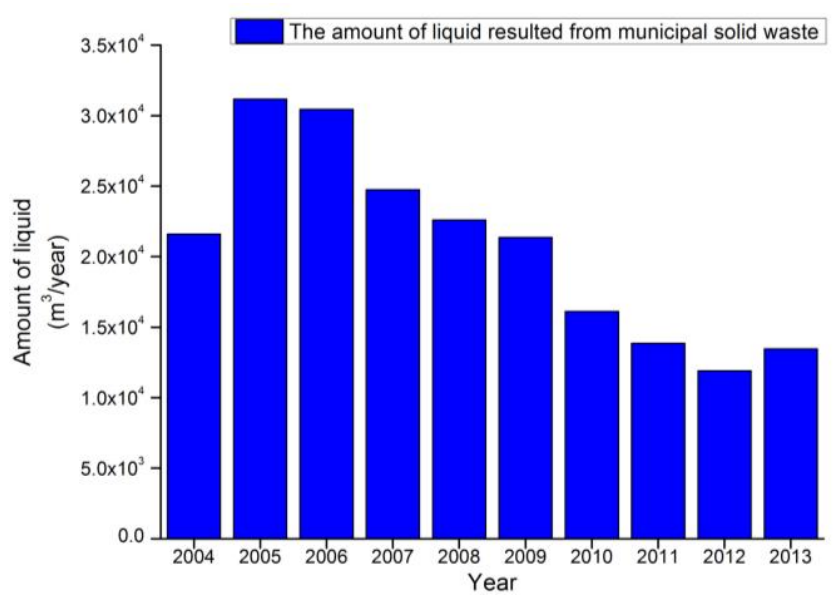

Fig. 14. The moisture content evaluation, from the total quantity of municipal solid waste kept in Piatra Neamt landfill [1].

It has been made an estimation of the liquid amount, resulted from the municipal solid waste quantity, deposited in the mentioned landfill (Figure 14) [1].

The monthly average variations of the meteorological/climatological parameters were used to evaluate the liquid amount that could be produced in the Piatra Neamt landfill: $746.58144 \mathrm{~m}^{3}$ per year. The landfill was working for ten years, therefore the liquid amount generated due to weather and other climatological conditions was $7465.8144 \mathrm{~m}^{3}[1]$.

\section{RESULTS AND DISCUSSION}

The landfill was closed in 2013, ten years after opening. 2004 is the first working year, and 2013 the tenth year of evaluation. The fifth year, 2008, is considered the first for leachate collection. This fact is confirmed by our calculations. The total liquid amount that could be formed in Piatra Neamt landfill is $214,702.12 \mathrm{~m}^{3}$. On the other hand, the total leachate amount that could be formed in this landfill could be evaluated by adding the following parameters [1]:

- the moisture content evaluation for all fractions of deposited municipal solid waste structure (Figure 14);

- the liquid amount evaluation, produced by weather and other climatological parameters. 


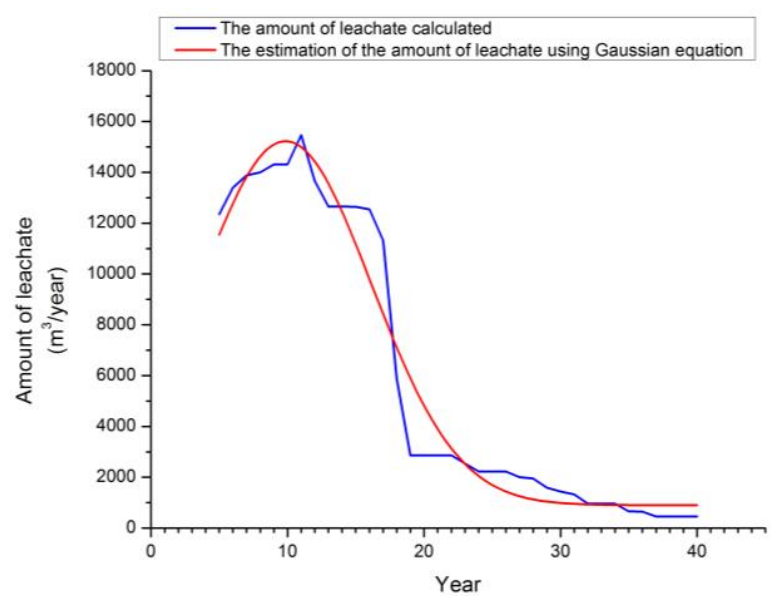

Fig. 15. The benchmarking/evaluation for the calculated leachate amount. An estimative mathematical model for leachate production capacity of Piatra Neamt landfill has been used [1].

A comparative analysis of [1] is presented in Figure 15:

- the amount of leachate is calculated using the moisture content of each fraction of the deposited municipal solid waste;

- the evaluation of the leachate amount was made using the estimative mathematical model for the leachate production capacity of Piatra Neamt landfill. The Origin Pro 8.5 software generated, using equation (4), an estimative mathematical model. The equation has a truth degree of $r^{2}=0.96029$.

$$
y=y_{0}+\left[\frac{A}{w \cdot \sqrt{\left(\frac{\pi}{2}\right)}} \cdot \exp \left(-2 \cdot\left(\frac{x-x c}{w}\right)^{2}\right)\right]\left[\mathrm{m}^{3} / \text { year }\right]
$$

where $y$ is the leachate amount (estimated annually), $y_{0}, w, x c, x$ and $A$ is a term of equation.

The terms of equation (4), take into consideration the landfill of Piatra Neamt, are presented in Table 1 [1].

Table 1. The Gaussian equation (that estimated the leachate amount that could be collected from Piatra Neamt landfill) terms [1].

\begin{tabular}{|c|c|}
\hline Term & Value \\
\hline$y_{0}$ & 901.63992 \\
\hline$x c$ & 9.85911 \\
\hline$w$ & 12.5949 \\
\hline$A$ & 226143.71913 \\
\hline
\end{tabular}

The amount of leachate collected in 2013 was taken from the specialized literature [1-3]. The amount of leachate for 2013 was worked out using the moisture content calculation method for each fraction; the result was 14313.47467 $\mathrm{m}^{3}$, much higher than the actual value, $990 \mathrm{~m}^{3}$. This can be due to the fact that that the collected leachate amount was not monitored and there was not any estimation of the leachate amount that could be produced in the body of landfill. A fraction of the leachate amount returns into the landfill after recirculation operations.

\section{CONCLUSIONS}

In Romania, the activity of waste depositing in ecological landfills, built in accord with the actual laws, is in a begining stage, from the 2000s, when Municipalities and County councils tried to develop some specific areas to create modern landfills, funded through European projects. 
The obtained data for the Piatra Neamt landfill, are presented below:

- the total amount of solid municipal waste kept during the active phase. The waste also presents fractions of industrial/construction waste, which were not taking into consideration in calculation;

- the average percentage of municipal solid waste composition was showed. This has been used in mathematical evaluation for the deposited waste. The fractions of municipal solid waste are:

- $\quad$ paper and cardboard waste;

- $\quad$ leather and textile waste;

- wood waste;

- $\quad$ organic waste;

- $\quad$ fine particles of waste;

- the monthly average variations of temperature and precipitation were showed, also, the monthly average variations of runoff and evapotranspiration were determined;

- the moisture content of each kind of the municipal solid waste deposited in the mentioned landfill was evaluated;

- it was performed a comparative analysis of the amounts of leachate calculated and estimated, using an mathematical model to calculate the capacity of leachate for this landfill. Regarding this, the total amount of leachate that could be formed there is $214702.12 \mathrm{~m}^{3}$.

The estimation of the post-closure leachate quantity was made for a period of 30 years. The correlation coefficient was 0.96029 .

The organic substance decomposition is the main process that produce leachate. On the other hand it appears behind extraction of organic contaminants from waste by means of the solvent effect of water. This product is very aggressive and can have a serious environmental impact in case of mismanagement.

\section{ACKNOWLEDGMENTS}

The authors gratefully acknowledge Environmental Protection Agency from Bacău and Piatra Neamt, SC Salubritas SA Piatra Neamt, SC Rossal SRL Roman and Meteo Romania, Department of Climatology for supplying the field data that were necessary for the research.

\section{REFERENCES}

[1] http://www.ub.ro/files/scoala-doctorala/Teze/Rezumat_limba_engleza.pdf (24.09.2016).

[2] Augenstein, D., Pacey, J., Modeling landfill methane generation, Proceedings of the Sardinia 91, Third International Landfill Symposium Sardinia, Italy. 1991.

[3] Agenția pentru Protecția Mediului Bacău, Autorizație Integrată de Mediu pentru Primăria Municipiului Piatra Neamt,, Serviciul Reglementări, 2006.

[4] Agenția pentru Protecția Mediului Neamț, Calitatea factorilor de mediu-Gestiune deșeuri, 2015.

[5] S.C. Bratner Servicii Ecologice S.A. Piatra Neamt, 2015.

[6] S.C. ROSSAL S.R.L. Roman Punct de lucru: Depozit Ecologic Piatra Neamț, Raport anual asupra calității mediului, 2015.

[7] Belciu, M., Studii şi cercetări cu privire la evaluarea aspectelor tehnologice pentru perioada de post-închidere a depozitelor de deşeuri municipale solide, Teză de doctorat, Universitatea "Vasile Alecsandri" din Bacău, 2016

[8] Meteo Romania Departamentul de Climatologie, 2015.

[9] Thornthwaite, C.W., An approach toward a rational classification of climate. Geographical Review, vol. 38, no. 1,1948, p. 55-94. 